\title{
Effect of Menstrual Cycle on Sport Performance in Archers
}

\author{
Pelin Akyol \\ Ondokuz Mayis University \\ Study Area:Samsun, Turkey \\ Coordinates: $41.2797^{\circ} \mathrm{N} ; 36.3361^{\circ} \mathrm{E}$
}

Keywords: Athletic Performance,Women physiology

\section{Abstract}

A total of 142 women participated in the 2019 archery archers competed in the Turkey championship. A questionnaire containing questions about the menstrual cycle was administered to the archers participating in the study. There was no statistical difference in the frequency of menstruation according to the age category of the archers, while a statistical difference was found in the bleeding times. While there was no statistically significant difference in bleeding times according to body mass index. A statistical difference was found in the frequency of menstruation. In general, regular and irregular menstruation did not differ statistically according to age category, but showed a signif icant difference according to body mass index categor. A statistically signif icant difference was found according to age groups in the periods when the performance was highest. There was no statistically signif icant difference according to age groups in case of being affected while shooting arrows in the menstrual period. Conclusively, the competitor archers who participated in our study had regular menstruation, but some of them had an increase in menstrual irregularity during the competition period. Perhaps irregularities during menstrual cycle is due to the stress experienced by many athletes during the preparation and competition period, the violent training that the athlete is in, and the emotional tensions experienced in addition to this, may increase these irregularities.

\section{Introduction:}

Menstruation or menstruation is a process in which adult women's reproductive capacity starts to function as a result of the development of ovarian status. Menstrual bleeding starts between the ages of 9-16 depending on various factors. Due to the nature of training in sports that require intense training, excessive physiological stress, and intense calorie expenditure delay the age of menarche (first menstruation). It has been reported that the menarche ages of national and Olympic athletes are significantly higher than their age groups (Fleck \& Kraemer, 2003). It is thought that athletes who train intensively during adolescence are more likely to have impaired menstrual functions. It is observed that menarche is delayed and menstrual disorders increase as the starting age of sports gets smaller (Kishali et al., 2007). The menstrual cycle is generally divided into three phases, (1) the early follicular phase characterized by low estrogen and progesterone, (2) the ovulation phase characterized by luteal phase characterized by high estrogen and progesterone. Although the primary function of these hormones is to support reproduction, research has highlighted that varying concentrations of estrogen and progesterone in the menstrual cycle also lead to numerous different and complex effects on many physiological systems, including cardiovascular, respiratory, metabolic, and neuromuscular parameters (Davis \& Hackney 2017; Ansdell et al., 2019).

Although a menstrual cycle usually takes 28 days in a woman, 21 to 35 days are the lower and upper limits of the normal. Menstrual bleeding continues for an average of 4 days and is considered to be the lower and upper limits of normal for 1 to 7 days. The reason for menstruation; is the sudden decrease of estrogen and progesterone, especially progesterone, at the end of the monthly cycle. Considering the effect of the menstrual period on performance in active women who do sports, some researchers stated that this high estrogen and low progesterone, and (3) the middle 
period had no negative effect on performance (Quadagno et al., 1991), while others stated that performance was negatively affected during this period (Wilson et al., 1991).

Every woman experiences the effects of premenstrual syndrome at different levels. Most women experience these situations as something they "have to endure" at some point in their life. It occurs with different symptoms in humans and the symptoms may differ according to people's expectations (Dickerson et al., 2003). In various studies, the prevalence rate of the premenstrual syndrome has been reported between $48 \%$ and $90 \%$ with different densities (Allais et al., 2012).

Although female athletes saw a decrease in their physical capacity during the menstrual period, some Olympic and world records were broken in almost all phases of the menstrual cycle (Gölünük et al., 2012). To date, the effects of estrogen and progesterone fluctuations on exercise performance are conflicting; studies have reported improved performance results in early follicular, ovulatory, and middle luteal phases; others showed no change in exercise performance between menstrual cycle phases (Bambaeichi et al., 2004; Ekenros et al., 2013; Vaiksaar et al., 2011). Therefore, it is clear that there is no consensus yet on the effects of menstruation on exercise performance. This study aims to investigate the effect of the menstrual period on sportive performance in female archers.

\section{Materials and Methods:}

The study included a total of 142 women who participated in the 2019 archery archers competed in the Turkey championship. Participation was on a voluntary basis. The average age of the participants is 25.21 years.

A questionnaire containing questions about the menstrual cycle previously used by Kisahli et al., (2007) and Atan et al., (2012).

The data measured in this study were used in the SPSS 23.0o statistical program. Chi-square, one-way analysis of variance and LSD tests were used in statistical processes. The level of signif icance was taken as $\mathrm{p}<0.05$.

\section{Results:}

Table-1: Height, body weight and menstrual starting age by age category

\begin{tabular}{cccc}
\hline Age Category & $\mathrm{N}$ & Mean & St.deviation \\
\hline Height $(\mathrm{cm})$ & \multicolumn{2}{c}{$\left(\mathrm{F} / \mathrm{LSD}: 12.95^{* *} ; 3>1.2\right)$} \\
15-18 age $(\mathrm{1})$ & 30 & 164.13 & 7.44 \\
19-25 age $(2)$ & 51 & 165,88 & 5,89 \\
$\geq 26$ age a $(3)$ & 61 & 170,05 & 4,65 \\
Total & & 142 & $167,306,25$
\end{tabular}

Weight (kg) (F/LSD: 4.59*; 3>1.2)

$\begin{array}{llll}15-18 \text { age }(1) & 30 & 56.20 & 10.34 \\ 19-25 \text { age }(2) & 51 & 58.63 & 10.36 \\ \geq 26 \text { age }(3) & 61 & 62.31 & 8.44 \\ \text { Total } & 142 & 59.70 & 9.82\end{array}$

Body mass index $(\mathrm{kg} / \mathrm{m} 2) \quad$ (F/LSD: 0.54$)$ $\begin{array}{llll}15-18 & \text { age }(1) & 30 & 20.81\end{array}$

\begin{tabular}{clcc} 
19-25 age (2) & 51 & 21.28 & 3.49 \\
$\geq 26$ age (3) & 61 & 21.52 & 2.59 \\
Total & 142 & 2129 & 3.06 \\
Menstrual start age (Year) & \multicolumn{1}{l}{ (F/LSD:0.78) } & \\
$15-18$ age (1) & 30 & 13.20 & 1.06 \\
$19-25$ age (2) & 51 & 13.14 & 1.25 \\
$\geq 26$ age (3) & 61 & 13.41 & 1.20 \\
Total & 142 & 13.27 & 1.19 \\
\hline
\end{tabular}

Table-2: Menstrual frequency and bleeding time according to age category and body mass index (n/\%)

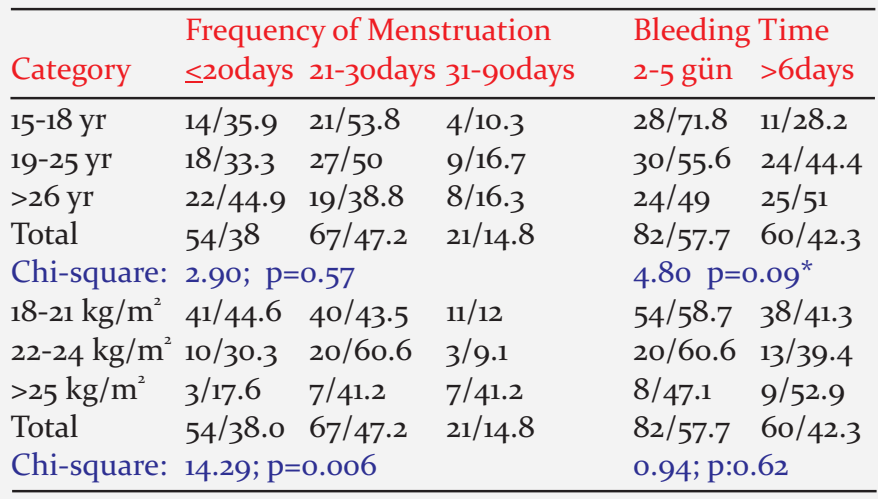

Table-3: Menstrual period according to age category and body mass index $(\mathrm{n} / \%)$

\begin{tabular}{lllllll}
\hline & \multicolumn{2}{l}{ General } & & & \multicolumn{3}{c}{ Competition period } \\
Category & RM & SRM & IM & RM & SRM & IM \\
\hline $15-18 \mathrm{yr}$ & $19 / 48.7$ & $11 / 28.2$ & $9 / 23.1$ & $7 / 23.3$ & $17 / 56.7$ & $6 / 20$ \\
$19-25 \mathrm{yr}$ & $31 / 57.4$ & $10 / 18.5$ & $13 / 24.1$ & $18 / 36.3$ & $19 / 37 \cdot 3$ & $14 / 27.5$ \\
$\geq 26 \mathrm{yr}$ & $26 / 53.1$ & $10 / 20.4$ & $13 / 26.5$ & $14 / 23$ & $35 / 57.4$ & $12 / 19.7$ \\
Total & $76 / 53.5$ & $31 / 21.8$ & $35 / 24.6$ & $39 / 27.5$ & $71 / 50$ & $32 / 22.5$ \\
Chi-square: & $1.48 ; \mathrm{p}=0.83$ & & $5.21 ; \mathrm{p}=0.266$ & \\
$18-21 \mathrm{~kg} / \mathrm{m}^{2}$ & $49 / 53.3$ & $23 / 25$ & $20 / 21.7$ & $25 / 27.2$ & $47 / 51.1$ & $20 / 21.7$ \\
$\mathbf{2 2 - 2 4} \mathrm{kg} / \mathrm{m}^{2}$ & $20 / 60.6$ & $7 / 21.2$ & $6 / 18.2$ & $8 / 24.2$ & $17 / 51.5$ & $8 / 24.2$ \\
$\geq 25 \mathrm{~kg} / \mathrm{m}^{2}$ & $7 / 41.2$ & $1 / 5 \cdot 9$ & $9 / 52.9$ & $6 / 35 \cdot 3$ & $7 / 41.2$ & $4 / 23.5$ \\
Total & $76 / 53.3$ & $31 / 21.8$ & $35 / 24.6$ & $39 / 27.5$ & $71 / 50.0$ & $32 / 22.5$ \\
Chi-square: & $9.60 ; \mathrm{p}=0.048$ & & $0.88 ; \mathrm{p}: 0.927$ & \\
\hline
\end{tabular}

RM: Regular mens.;SRM: Sometimes Regular mens.; IM: Irregular Mens.

Table 4:Affect competition and training performance before and during menstruation

\begin{tabular}{lllllllll}
\hline & \multicolumn{3}{c}{ Effect: premenstrual } & \multicolumn{4}{c}{ Effect: menstrual period } \\
Category & AN & SN & NA & SP & AN & SN & NA & SP \\
\hline $15-18 \mathrm{yr}$ & $2 / 6.7$ & $8 / 26.7$ & $4 / 13.3$ & $16 / 53.3$ & $6 / 20$ & $17 / 56.7$ & $5 / 16.7$ & $2 / 6.7$ \\
$19-25 \mathrm{yr}$ & $4 / 7.8$ & $26 / 51$ & $4 / 7.8$ & $17 / 33.3$ & $12 / 23.5$ & $28 / 54.9$ & $9 / 17.6$ & $2 / 3.9$ \\
$\geq 26 \mathrm{yr}$ & $9 / 14.8$ & $20 / 32$. & $10 / 16.4$ & $22 / 36.1$ & $18 / 29.5$ & $33 / 54.1$ & $8 / 13.1$ & $2 / 3.3$ \\
Total & $15 / 10.6$ & $54 / 38$ & $18 / 12.7$ & $55 / 38.7$ & $36 / 25.4$ & $78 / 54.9$ & $22 / 15.5$ & $6 / 4.2$ \\
Chi-square; 9.27 & p=0.159 & & Chi-square 1.81 & p=o.936 \\
\hline AN:Always -ve; SN:Sometimes-ve; NA: Notaffect atall SP:Sometimes+ve
\end{tabular}

\section{Discussion:}

It has been emphasized that varying estrogen and progesterone concentrations in the menstrual cycle also lead to numerous different and complex effects on many physiological systems, including cardiovascular, respiratory, metabolic, and neuromuscular parameters (Davis \& Hackney 2017; Ansdell et al., 2019). Studies are 
Table 5. Affect competition and training performance before and during menstruation

\begin{tabular}{llllllll}
\hline & \multicolumn{2}{l}{ Period with the Highest Performance } & \multicolumn{2}{l}{ Period of She Felt the Worst } & \multicolumn{2}{c}{$\begin{array}{l}\text { Affect the performance of arrow } \\
\text { shooting during menstruation } \\
\text { Affect }\end{array}$} \\
Category & MP & PM & PtM & MP & PM & PtM & Indect \\
Indecisive
\end{tabular}

indicating that the menstrual cycle may have effects on exercise performance (Janse de Jonge et al., 2003). It was determined that the age of menstruation of the archers in this study was 13.27 years (Table-1). While there was a statistically significant difference in height and bodyweight of archers as per age category, the difference between Body Mass Index and menstrual age is insignificant.

Bruinvels et al., (2016) sought an answer to the question of whether elite and non-elite marathon runners affect the amount of bleeding in the menstrual cycle and their training and competition performance due to iron deficiency caused by heavy bleeding. Interestingly, 36.7\% of elite marathon runners stated that they had a heavy menstrual cycle, $51.1 \%$ affected their training and competition performances and $78.9 \%$ of them took supplements due to iron deficiency due to bleeding. With this study, it is known that there are studies that found that especially endurance athletes are generally susceptible to amenorrhea and oligomenorrhea as a result of a relative lack of energy associated with a high training volume (Nattiv et al., 2007; Nazem \& Ackerman, 2012). In this study, those who had menstruation between 21.30 days were found to be $47.2 \%$ and those who had irregular periods (3190 days) were found to be $14.48 \%$. Those who stated the bleeding time as 2-5 days were found to be $57.7 \%$ and those who stated 6 days or more as $42.3 \%$ (Table-2). While there was no statistical difference in the frequency of menstruation according to age category, a statistical difference was found in the bleeding times. While there was no statistically significant difference in bleeding times according to body mass index, a statistical difference was found in the frequency of menstruation. In our study, we can say that athletes had regular menstruation, and the rate of athletes who had a bleeding time of more than 6 days was similar to the study conducted by Bruinvels et al., (2016). We can say that the menstrual cycles of the archers, whose body mass index is within the limits of being healthy, are more regular. It has been shown that heavy menstrual bleeding is common in the exercising population. However, it is stated that more research is needed to explore the effect of a heavy bleeding menstrual period and iron deficiency on performance (Bruinvels et al., 2016).

Çetin et al. (2005) stated that $18 \%$ of students who showed signs of premenstrual tension had a disturbed menstrual period during a four-year follow-up period. The reproductive system of women is very sensitive to physiological stress and reproductive abnormalities (delayed menarche, amenorrhea) is observed in approximately $79 \%$ of female athletes. This high rate is not only due to the physical aspect of the exercise but also to the psychological stress of the training and competition, weight loss, and fat percentage. Menstrual disturbances are common in athletic women, with prevalence ranging from 6 to $78 \%$ (O'Donnell \& De Souza, 2004; Goodman \& Warren, 2005; Redman \& Loucks, 2005; Torstveit \& Sundgot-Borgen, 2005). Lydon et al., (2020) stated $18.71 \%$ of active female athletes had painful menstrual periods and used painkillers during this period. They stated that menstrual disorders can affect the quality of life, training, and athletic performance of female athletes. They also stated that ideally, these conditions should be screened and determined before the competition, and contestant athletes should be managed proactively in the competition. In general, regular and irregular menstruation did not differ statistically according to age category but showed a significant difference according to body mass index category (Table-3). In general, regular and irregular menstruation did not differ statistically according to age category but showed a significant difference according to body mass index category. Those with a Body Mass Index of $25 \mathrm{~kg} / \mathrm{m}^{2}$ and above have a higher percentage of irregular menstruation. The difference between groups during the competition period is insignificant. The competition period has increased those who sometimes have irregular periods. It is thought that this may be caused by increased training intensity and stress-related factors during the competition period. In irregular menstruation, the condition of menstruation is similar during the competition and outside the competition period. Some archers who have irregular periods also have irregular periods during the competition period.

McNulty et al., (2020) investigated whether it affects exercise performance in amenorrheic women and stated that, on average, exercise performance may decrease insignificantly in the early follicular phase of the menstrual cycle compared to all other stages of the menstrual cycle. Especially estrogen is thought to have an anabolic effect on skeletal muscle (Baltgalvis et al., 2010). To date, the effects of estrogen and progesterone fluctuations on exercise 
performance are conflicting, studies have reported improved performance results in early follicular, ovulatory, and middle luteal phases (Tenan et al., 2016; Bambaeichi et al., 2004; Ekenros et al., 2013). Another study showed no change in exercise performance between phases of the menstrual cycle (Vaiksaar et al., 2011). Rodrigues et al., 2019 found that women at different stages of the menstrual cycle produced different levels of muscle strength. They expressed the late luteal phase, the period in which they showed the least muscle power capacity and the middle follicular phase as the period in which the subjects presented the greatest maximal muscle strength values. Tsuneura et al., (2013) stated in a study that changes in exercise performance during the menstrual cycle can fluctuate. Women can also be affected by premenstrual syndrome manifesting in emotional, behavioral, and physical symptoms. The American College of Obstetricians and Gynecologists believe that around $85 \%$ of menstruating women experience at least one symptom of premenstrual as part of their monthly cycle. In this study, those who said that competition and training had a positive effect on performance during the premenstrual period were the highest with $38.7 \%$. (Table-4). There was no statistically significant difference between the age groups in the effect of competition and training performance before and during the menstrual period ( $p>0.05$ ). While some decreases were observed in the performance of some athletes during the menstrual phase (Smekal et al., 2007; Lloyd et al., 2000), results are indicating that some athletes showed a higher level of cardiovascular, neuromuscular, and metabolic performance during the menstrual phase (Iwamoto et al., 2002; Schoene et al., 1981). In another study, 2/3 of the participants stated that despite the abdominal thoracolumbar pain, discomfort, and irritability they felt during their menstrual cycles, this situation did not affect their performance. The gold medals they won in this period also support their declarations (Sambanis et al., 2003). In the study conducted by Senatore et al., (2019) on gymnasts, psycho-physical stress generally causes a decrease in sports performance caused by physical fatigue and especially weight in the lower extremities, and this is a feeling that gymnasts describe as "weakness". Karacan (2000), in his study, measured the auditory reaction times of both the experimental and control groups in the specified periods of the menstrual cycle and could not detect a significant difference in the comparisons between periods. Although the auditory reaction time of the experimental group consisting of different branches was lower than the nonathlete control group, no statistically significant result was obtained in the comparisons between the groups in all three periods of the menstrual cycle. Çavlıca et al., (2009), in their study, think that the pain sensations of athletes during exercise decrease in the menstrual phase, and it has been suggested that the training intensity of athletes during this period can be increased accordingly. Postmenstrual days are considered by most athletes to be the best period for sports performance (Fischetto \& Sax, 2013). Serin \& Afyon (2019) stated in their study that the menstrual period did not harm shooting performance in archers aged between 18 and 30 . As a result of their study, they did not find a significant difference between the tempo and endurance values of the 2nd and 14th day of the menstrual period (ovulation day). Some studies have found no effect of the menstrual cycle on muscle strength (Arazi et al., 2019; Köse, 2018). In this study, the period with the highest performance was found to be $52.1 \%$ before and $42.3 \%$ after menstruation. Those who say they are affected when shooting arrows while menstruating are $43.0 \%$, while those who say they are not affected are $32.4 \%$ and those who are indecisive are $24.6 \%$. (Table-5). A statistically significant difference was found according to age groups in the periods when the performance was highest $(\mathrm{p}<0.05)$. The post-menstrual period in the 15-18 age group, and the premenstrual period in the 19-25 age group, and the age group 26 and above are higher. The period when he feels worst is the menstrual period with $59.9 \%$. No significant difference was found according to age groups in the period in which they felt the worst ( $>>0.05$ ). However, the percentage of feeling bad in the menstrual period is higher in the $15-18$ age group.

As a result, the competitor archers who participated in our study had regular menstruation, but some of them had an increase in menstrual irregularity during the competition period. Most of the archers stated that they feel bad during the menstrual period. However, in our study, it is not possible to say with certainty that the menstrual period harmed performance. It is thought that irregularities occur in the menstrual cycle due to the stress experienced by many athletes during the preparation and competition period, the violent training that the athlete is in, and the emotional tensions experienced in addition to this, may increase these irregularities. Studies are recommended to reduce their stressful situations.

\section{References:}

Allais, G., Gabellari, I.C., Burzio, C., Rolando, S., De Lorenzo, C., Mana, O. \& Benedetto, C. (2012): Premenstrual syndrome and migraine. Neurol.Sci. Springer, 33(1):111-115.

Ansdell, P., Brownstein, C.G., Škarabot, J., Hicks, K.M., Simoes, D.C., Thomas, K., Howatson, G., Hunter, S.K. \& Goodall, S. (2019): Menstrual cycle-associated modulations in neuromuscular function and fatigability of the knee extensors in eumenorrheic women.J. Appl. Physiol., 126(6):1701-12.

Atan, T., Çicek, G. \& Imamoglu, O. (2012): Menstrual status of athletes and non-athletes, energy education science and technology Part B. Soc. Edu. Stud., 1:1011-1017.

Arazi, H., Nasiri, S. \& Eghbali, E. (2019): Is there a difference toward strength, muscular endurance, anaerobic power and hormonal changes between the three phases of the menstrual cycle of active girls? Apun. Med. Esp., 54:65-72.

Baltgalvis, K.A., Greising, S.M., Warren, G.L. \& Lowe, D.A. (2010): Estrogen regulates estrogen receptors and antioxidant gene 


\section{ORIGINAL ARTICLE}

expression in mouse skeletal muscle. PLoSOne, 5(4):101-64.

Bambaeichi, E., Reilly, T., Cable, N.T. \& Giacomoni, M. (2004): The isolated and combined effects of menstrual cycle phase and time-of-day on muscle strength of eumenorrheic females. Chronobiol. Int., 21 (4-5):645-6o.

Bruinvels, G., Burden, R., Brown, N., Richards, T. \& Pedlar, C. (2016): The Prevalence and Impact of Heavy Menstrual Bleeding (Menorrhagia) in Elite and Non-Elite Athletes. $\underline{P L O S}$ ONE, 11(2):eo149881.

Çavlica, B., Yücel, S.B., Darçin, N., Mirzai, I.D. \& Erbüyün, K. (2009): Pain perception of professional volleyball players during different phases of mensturation. Agri., 21(1):29-35.

Çetin, S.K., Akdeniz, F. \& Tama, M. (2005): Depresif Bozukluk Tanili Genç Kizlarda Adet Öncesi Belirti Dagilimi ve Siddeti. Anadolu Psikiyatri Dergisi, 6:145-153.

Davis, H.C. \& Hackney, A.C. (2017): The hypothalamicpituitary-ovarian axis and oral contraceptives: regulation and function. In: Hackney AC, (Ed.). Sex Hormones, Exercise and Women: Scientific and Clinical Aspects. Pub. by: London: Springer.

Dickerson, Lori, M., Mazyck, Pamela, J. Hunter, \& Melissa, H. (2003): Premenstrual Syndrome. Am. Fam. Physic., 67(8): 1743-1752.

Ekenros, L., Hirschberg, A.L., Heijne, A. \& Fridén, C. (2013): Oral contraceptives do not affect muscle strength and hop performance in active women. Clin. J. Sport. Med., 23(3):202-7.

Fischetto, G. \& Sax, A. (2013): The Menstrual Cycle and Sport Performance. New Stud. Athletics, 28,(3/4):57-69.

Fleck, S.J. \& Kraemer, J.W. (2003): Designing resistance training programs. 7. Edition. Pub. by: Human Kinetics, Inc., P. -520

Goodman, L.R. \& Warren, M.P. (2005): The Female athlete and Menstruel Function. Curr. Opin. Obstet. Gynecol., 17:466-470.

Gölünük, S., Tasmektepligil, M.Y. \& Imamoglu, O. (2010): Bedeni ve Ruhsal Baskinin Menstruasyon Düzenine Etkisi. Selçuk Üniversitesi Beden Egitimi ve Spor Bilim Dergisi, 12(1):1-5.

Iwamoto, Y., Kubo, J. \& Ito, M. (2002): Variation in maximal voluntary contraction during the menstrual cycle. Ipn. J. Phys. Fit. Sports. Med., 51:193-201.

Janse de Jonge, X.A., Boot, C.R., Thom, J.M., Ruell, P.A. \& Thompson, M.W. (2001): The influence of menstrual cycle phase on skeletal muscle contractile characteristics in humans. J. Physiol., 1(530)1:161-6.

Karacan, S. (2000): Bayan Sporcularda Menstruasyon ve Premenstrual Sendromun Bazi Temel Motorik Özelliklere ve Fizyolojik Parametrelere Etkisi. Gazi Üniversitesi Beden Egitimi Spor Yüksek Okulu Yayinlanmamis Yüksek Lisans Tezi , Ankara.

Kishali, N.F., Imamoglu, O., Katkat Atan, T. \& Akyol, P. (2007): Effects of menstrual cycle on sports performance a physical education. Int. J. Neurosci., 116(12):1549-1563.

Köse, B. (2018): Analysis of the effect of menstrual cycle phases on aerobic-anaerobic capacity and muscle strength. L. Edu. Train Stud., 6(8):23-28.

Lloyd, G.W., Patel, N.R,, McGing, E., Cooper, A.F., BrennandRoper, D. \& Jackson, G. (2000): Does angina vary with the menstrual cycle in women with premenopausal coronary artery disease? Heart, 84:189-92.

Lydon, K., Madigan, S. \& Rankin, A. (2020): 244 Prevalence and burden of menstrual disorders in athletes: a questionnaire
Ambient Science, 2020: Vol. 07(Sp1); 198-202 DOI:10.21276/ambi.2020.07.sp1.oa27

study. Brit. J. Sports Med., 54(1):A101.

McNulty, K.L., Elliott-Sale, K.J., Dolan, E., Swinton, P.A., Ansdell, P., Goodall, S. \& Hicks, K.M. (2020): The effects of menstrual cycle phase on exercise performance in eumenorrheic women: a systematic review and meta-analysis. Sports Med., :1-15.

Nazem, T.G. \& Ackerman, K.E. (2012): The female athlete triad. Sports Health, 4:302-11.

Nattiv, A., Loucks, A.B., Manore, M.M., Sanborn, C.F., SundgotBorgen, J. \& Warren, M.P. (2007): American College of Sports Medicine position stand. The female athlete triad. American College of Sports Medicine. Med. Sci. Sports Exer., 39:1867-82.

O'Donnel, E. \& De Souza, M.J. (2004): The Cardiovascular effect of chronic Hypoestrogenism in Amenorrhoeic athletes: a critical review. Sports Med., 34:601-627.

Tostveit, M.K. \& Sundgot- Borgen, J. (2005): The Female Athlete Triad: are elite athletes at increased risk? Med. Sci. Sports Exer., 37:184-193.

Redman, L.M., Scroop, G.C. Norman, R.J. (2003): Impact of menstrual cycle phase on the exercise status of young, sedentary women. Eu. J. Appl. Physiol., 90(5-6):505-13.

Rodrigues, P., de Azevedo, M.C. \& Wharton, L. (2019): Effect of menstrual cycle on muscle strength. J. Exer. Physiol. Online, 22(5):89-96.

Smekal, G., von Duvillard, S.P., Frigo, P., Tegelhofer, T., Pokan, R., Hofmann. P., Tschan, H., Baron, R., Wonisch, M., Renezeder, K. \& Bachl, N. (2007): Menstrual cycle: no effect on exercise cardiorespiratory variables or blood lactate concentration. Med. Sci. Sports Exer., 39:1098-1106.

Sambanis, M., Kofotolis, N., Kalogeropoulou, E., Noussios, G., Sambanis, P. \& Kalogeropoulos, J. (2003): A study of the effects on the ovarian cycle of athletic training in different sports. $L$ Sports Med. Phys. Fitness, 43:398-403.

Schoene, R.B., Robertson, H.T., Pierson, D.J. \& Peterson, A.P. (1981): Respiratory drives and exercise in menstrual cycles of athletic and nonathletic women. J. Appl. Physiol., 50:1300-5.

Senatore, B., Pisapia, F. \& Di Domenico, F. (2019): Menstrual cycle disorders in rhythmic gymnastics athletes. J. Phy. Edu. Sport, 19:2005-2010.

Serin, S. \& Afyon, A.Y. (2019): Investigation factors that effect shooting performance in the menstrual period of female archeryathletes. Int. J. Phys. Edu. Sports Health, 6(5):33-38.

Tostveit, M.K. \& Sundgot-Borgen, J. (2005): The Female Athlete Triad: are elite athletes at increased risk? Med. Sci. Sports Exer., 37:184-193.

Tsuneura, A., Sugiyama, E. \& Yasuda, N. (2013): Evaluation of athletic performance level based on free throw shooting during menstrual cycle phase. ASICS Conf./I. Sci. Med. Sport, 16S:e59-e83.

Quadagno, D., Faquin, L., Lim, G.N., Kuminka, W. \& Moffatt, R. (1991): The menstrual cycle: Does it affect athletic performance? Physic. Sports Med., 19(3):121-4.

Wilson, C.A., Abdenour, T.E. \& Keye, W.R. (1991): Menstrual disorders among intercollegiate athletes and non athletes: Perceived impact on performance. Athletic Train., 26:170-177.

Vaiksaar, S., Jürimäe, J., Mäestu, J., Purge, P., Kalytka, S., Shakhlina, L. \& Jurimae. T. (2011): No effect of menstrual cycle phase and oral contraceptive use on endurance performance in rowers. J. Strength Cond. Res., 25(6):1571-8. 